\title{
Enzyme Activities in Oleaginous Yeasts Accumulating and Utilizing Exogenous or Endogenous Lipids
}

\author{
By JANE E. HOLDSWORTH, ${ }^{1} \uparrow$ MARTEN VEENHUIS ${ }^{2}$ AND \\ COLIN RATLEDGE ${ }^{1 *}$ \\ 'Department of Biochemistry, University of Hull, Hull HU6 $7 R X, U K$ \\ 'Department of Electron Microscopy, Biological Centre, University of Groningen, \\ Kerklaan 30, 9751 NN Haren, The Netherlands
}

(Received 11 May 1988: revised 4 July 1988)

\begin{abstract}
The activities of ATP : citrate lyase (ACL; EC 4.1.3.8), carnitine acetyltransferase (CAT; EC 2.3.1.7), $\mathrm{NADP}^{+}$-dependent isocitrate dehydrogenase (ICDH; EC 1.1.1.42), isocitrate lyase (ICL; EC 4.1.3.1) and malic enzyme (malate dehydrogenase; EC 1.1.1.40) were measured in four oleaginous yeasts, Candida curvata D, Trichosporon cutaneum and two strains of Rhodosporidium toruloides, grown either to accumulate lipid, or to utilize their own lipid reserves or an exogenous supply of lipid. During lipid utilization, activities of ACL and malic enzyme diminished to low levels; CAT and ICL increased considerably in activity and ICDH activity was slightly increased but catalase (EC 1.11.1.6) diminished in activity in both strains of $R$. toruloides. In all cases, yeasts utilizing exogenous lipid showed greater changes in enzyme activities than cells utilizing their endogenous reserves. Electron micrographs of Candida curvata D showed proliferation of peroxisomes in starved cells utilizing their own lipid reserve though peroxisomes were more in evidence when the yeast had been grown on exogenous lipid. In Lipomyces starkeyi, which shows only minimal utilization of its stored lipid and furthermore cannot grow on exogenous lipid, only the occasional peroxisome was seen when cells were starved of carbon.
\end{abstract}

\section{INTRODUCTION}

Micro-organisms are subjected to great changes in nutrient availability in their natural environments. It is vital therefore that they are able to withstand periods of starvation and to recover once normal conditions are resumed. Holdsworth and Ratledge (1987) demonstrated that oleaginous yeasts, if starved of a supply of carbon, can utilize their oil reserves in the presence of an exogenous nitrogen source. The onset of lipid turnover in such yeasts occurs within $1.5 \mathrm{~h}$ of switching from nitrogen-limitation to carbon-starvation conditions. This rapidity would suggest that enzyme activities involved in the conversion of lipid to biomass would be highly controlled and that significant changes in these activities would occur upon this transition.

This paper attempts to gain insight into the control of lipid turnover by examining the activities of six enzymes in oleaginous yeasts during lipid accumulation and lipid turnover, and also during growth on an exogenous source of lipid. Batch culture and a two-stage continuous culture have been used to explore this phenomenon. We have also examined the yeasts by electron microscopy for evidence of the induction of peroxisomes during lipid utilization. Such

$\dagger$ Present address: DSIR, Industrial Processing Division, Petone, New Zealand.

Abbreviations: ACL, ATP:citrate lyase; CAT, carnitine acetyltransferase; ICDH, NADP ${ }^{+}$-dependent isocitrate dehydrogenase; ICL, isocitrate lyase. 
microbodies are associated with the $\beta$-oxidation pathway for degradation of fatty acids in yeasts growing on alkanes (Fukui \& Tanaka, 1979a, $b, 1981$ ) and have recently been shown to be induced in Saccharomyces cerevisiae grown aerobically on oleic acid (Veenhuis et al., 1987). A brief report of some of these findings has previously appeared (Holdsworth \& Ratledge, 1986).

\section{METHODS}

Yeasts. These were obtained from the following culture collections: Centraalbureau voor Schimmelcultures, Delft, Netherlands (CBS); National Collection of Yeast Cultures, Norwich, UK (NCYC); American Type Culture Collection (ATCC). Candida curvata D and Trichosporon cutaneum 40 were kindly supplied by Professor E. G. Hammond, Iowa State University, Ames, Iowa, USA.

Media. The basal media for batch and continuous culture experiments contained the following constituents ( $\mathrm{gl}^{-1}$ ): $\mathrm{KH}_{2} \mathrm{PO}_{4}, 7 \cdot 0 ; \mathrm{Na}_{2} \mathrm{HPO}_{4}, 2 \cdot 0 ; \mathrm{MgSO}_{4} .7 \mathrm{H}_{2} \mathrm{O}, 1 \cdot 5 ;$ yeast extract, $1.5 ; \mathrm{CaCl}_{2} .2 \mathrm{H}_{2} \mathrm{O}, 0 \cdot 1 ; \mathrm{FeCl}_{3} .6 \mathrm{H}_{2} \mathrm{O}$, $0.008 ; \mathrm{ZnSO}_{4} .7 \mathrm{H}_{2} \mathrm{O}, 0.001 ; \mathrm{CuSO}_{4} .5 \mathrm{H}_{2} \mathrm{O}, 0.0001 ; \mathrm{Ca}\left(\mathrm{NO}_{3}\right)_{2} .6 \mathrm{H}_{2} \mathrm{O}, 0.0001 ; \mathrm{MnSO}_{4} .5 \mathrm{H}_{2} \mathrm{O}, 0.0005$; with $\mathrm{NH}_{4} \mathrm{Cl}$ at $0.5 \mathrm{~g} \mathrm{l}^{-1}$ and glucose at $30 \mathrm{~g} \mathrm{l}^{-1}$ for nitrogen-limited media; $\mathrm{NH}_{4} \mathrm{Cl}_{\text {a }} 3 \mathrm{~g} \mathrm{l}^{-1}$ and no carbon source for carbon starvation conditions; and $\mathrm{NH}_{4} \mathrm{Cl}_{\text {a }} 3 \mathrm{~g} \mathrm{l}^{-1}$ and trioleylglycerol at $15 \mathrm{~g}^{-1}$ for triolein medium. The $\mathrm{pH}$ in all media was adjusted to $5 \cdot 5$ prior to the addition of carbon source and micronutrients.

Batch culture medium was sterilized in situ by autoclaving at $121^{\circ} \mathrm{C}$ for $15 \mathrm{~min}$. Medium for continuous culture experiments was sterilized by membrane filtration.

Batch culture experiments. Yeasts were cultvated in 1 litre vortex-aerated bottles at $30^{\circ} \mathrm{C}$ containing $700 \mathrm{ml}$ nitrogen-limited medium (Marshall et al., 1973). After $48 \mathrm{~h}$, approximately $200 \mathrm{ml}$ of the culture was aseptically transferred to a similar vessel containing $400 \mathrm{ml}$ carbon starvation medium already at $30^{\circ} \mathrm{C}$. Yeasts were grown in the second vessel for a further $24 \mathrm{~h}$. Cells were harvested after growth in each vessel. Cells were also cultivated on triolein medium in a similar vessel for $48 \mathrm{~h}$.

Two-stage continuous culture experiments. Candida curvata $\mathrm{D}$ was grown in two-stage continuous culture with the first vessel being a 1.51 chemostat with an operating volume of 1.251 . The second vessel was a similar unit with a working volume of 3.751 . Experimental conditions were as described by Holdsworth \& Ratledge (1987). Cells were harvested after steady states had been attained in each vessel.

Preparation of cell-free extracts and enzyme assays. Cells were harvested by centrifuging at $5000 \mathrm{~g}$ for $10 \mathrm{~min}$ at $4{ }^{\circ} \mathrm{C}$ and washed twice by resuspension in $50 \mathrm{~mm}-\mathrm{KH}_{2} \mathrm{PO}_{4} / \mathrm{Na}_{2} \mathrm{HPO}_{4}$ buffer $\mathrm{pH} 7.5$ and centrifuged as before. The yeast was then suspended in $30 \mathrm{mM}-\mathrm{KH}_{2} \mathrm{PO}_{4} / \mathrm{Na}_{2} \mathrm{HPO}_{4}$ buffer, $\mathrm{pH} 7.5\left(0.5 \mathrm{~g}\right.$ wet wt ml $\left.{ }^{-1}\right)$ unless otherwise stated in the relevant enzyme assay method (see below), and disrupted by passage through a pre-cooled French pressure cell at $35 \mathrm{MPa}$. Whole cells and debris were removed by centrifuging at $48000 \mathrm{~g}$ for $30 \mathrm{~min}$ at $4{ }^{\circ} \mathrm{C}$ and the supernatant filtered through Whatman no. 1 filter paper to remove any solidified lipid. The filtrate was retained for enzyme assays.

Assays for enzymes were done using a double-beam, temperature controlled spectrophotometer. The following enzymes were assayed at $30^{\circ} \mathrm{C}$ : ATP : citrate lyase (ACL; EC 4.1.3.8) (Srere, 1962); malic enzyme (malate dehydrogenase; EC 1.1.1.40) (Hsu \& Lardy, 1969); carnitine acetyltransferase (CAT; EC 2.3.1.7) (Kohlaw \& Tan-Wilson, 1977); NADP+-dependent isocitrate dehydrogenase (ICDH; EC 1.1.1.42) (Kornberg, 1955) and isocitrate lyase (ICL; EC 4.1.3.1) (McFadden, 1969). Catalase (EC 1.11.1.6) was assayed at $25^{\circ} \mathrm{C}$ by measuring the decomposition of peroxide to $\mathrm{H}_{2} \mathrm{O}$ and $\mathrm{O}_{2}$ with the concomitant decrease in $\mathrm{A}_{240}$ following the manufacturer's (Sigma) directions. Soluble protein was estimated by the method of Bradford (1976) with bovine serum $\gamma$-globulin as the standard. All assays were done in triplicate on two different extracts; variations were usually less than $10 \%$ of the mean.

Electron microscopy. Yeast cells were harvested and washed once with water. The cells were fixed with $\mathrm{KMnO}_{4}$ $(1.5 \%, \mathrm{w} / \mathrm{v})$ for $20 \mathrm{~min}$ at room temperature, washed twice in distilled $\mathrm{H}_{2} \mathrm{O}$ and post-stained with uranyl acetate $(1 \% \mathrm{w} / \mathrm{v}$ in water) for $2 \mathrm{~h}$. They were then dehydrated in a graded ethanol series and embedded in Epon 812 . The material was cut on a LKB ultramicrotome with a diamond knife and examined in a Philips EM300 electron microscope.

\section{RESULTS}

Enzymic changes accompanying lipid degradation in batch culture

Enzymes examined in the various yeasts were selected on the basis of their probable involvement in lipid synthesis or degradation. Changes in their activities were followed upon transferring yeasts from a nitrogen-limited growth medium, which induced lipid accumulation, to a carbon starvation medium which promoted utilization of the stored lipid (Table 1). The same enzyme activities were also measured in the yeasts grown on triolein as a source of exogenous lipid (Table 1). 
Table 1. Enzyme activities in yeasts cultivated on nitrogen-limited, carbon-starvation and triolein media in batch culture

\begin{tabular}{|c|c|c|c|c|c|c|c|}
\hline \multirow[b]{2}{*}{ Yeast } & \multirow[b]{2}{*}{ Growth medium* } & \multicolumn{6}{|c|}{ Enzyme activity [nmol (mg protein $)^{-1}$ ] } \\
\hline & & $\mathrm{ACL}$ & CAT & Catalase & ICDH & ICL & $\begin{array}{c}\text { Malic } \\
\text { enzyme }\end{array}$ \\
\hline C. curvata $\mathrm{D}$ & $\begin{array}{l}\text { Nitrogen-limited } \\
\text { Carbon-starvation } \\
\text { Triolein }\end{array}$ & $\begin{array}{r}17 \\
2 \\
1\end{array}$ & $\begin{array}{l}239 \\
189 \\
722\end{array}$ & $\begin{array}{l}51 \times 10^{3} \\
59 \times 10^{3} \\
84 \times 10^{3}\end{array}$ & $\begin{array}{l}31 \\
49 \\
41\end{array}$ & $\begin{array}{r}1 \\
16 \\
122\end{array}$ & $\begin{array}{r}111 \\
85 \\
0\end{array}$ \\
\hline T. cutaneum 40 & $\begin{array}{l}\text { Nitrogen-limited } \\
\text { Carbon-starvation } \\
\text { Triolein }\end{array}$ & $\begin{array}{r}30 \\
7 \\
0\end{array}$ & $\begin{array}{r}56 \\
85 \\
255\end{array}$ & $\begin{array}{l}51 \times 10^{3} \\
64 \times 10^{3} \\
70 \times 10^{3}\end{array}$ & $\begin{array}{r}71 \\
95 \\
103\end{array}$ & $\begin{array}{r}4 \\
29 \\
77\end{array}$ & $\begin{array}{l}34 \\
35 \\
12\end{array}$ \\
\hline $\begin{array}{l}R . \text { toruloides } \\
\text { CBS } 14\end{array}$ & $\begin{array}{l}\text { Nitrogen-limited } \\
\text { Carbon-starvation } \\
\text { Triolein }\end{array}$ & $\begin{array}{r}65 \\
11 \\
8\end{array}$ & $\begin{array}{r}95 \\
92 \\
469\end{array}$ & $\begin{array}{l}4 \times 10^{3} \\
2 \times 10^{3} \\
2 \times 10^{3}\end{array}$ & $\begin{array}{l}45 \\
40 \\
64\end{array}$ & $\begin{array}{r}7 \\
62 \\
137\end{array}$ & $\begin{array}{l}37 \\
20 \\
21\end{array}$ \\
\hline $\begin{array}{l}R . \text { toruloides } \\
\text { ATCC } 26217\end{array}$ & $\begin{array}{l}\text { Nitrogen-limited } \\
\text { Carbon-starvation } \\
\text { Triolein }\end{array}$ & $\begin{array}{r}74 \\
13 \\
3\end{array}$ & $\begin{array}{r}96 \\
101 \\
705\end{array}$ & $\begin{array}{l}4 \times 10^{3} \\
2 \times 10^{3} \\
1 \times 10^{3}\end{array}$ & $\begin{array}{l}32 \\
43 \\
49\end{array}$ & $\begin{array}{r}4 \\
65 \\
144\end{array}$ & $\begin{array}{r}18 \\
25 \\
0\end{array}$ \\
\hline
\end{tabular}

* Nitrogen limited = lipid accumulating; carbon starvation = endogenous lipid utilizing; triolein = exogenous lipid utilizing.

$A C L$. ACL supplies the prerequisite acetyl-CoA for fatty acid biosynthesis in oleaginous yeasts (Boulton \& Ratledge, $1983 a, b$ ). In all species of yeast examined, there was a decrease in activity of ACL when the yeast utilized either endogenous or exogenous lipid. On mixing volumes of extracts from triolein-grown cells and nitrogen-limited cells containing equal concentrations of protein, ACL activity was found to be half of the sum of the individual activities. This indicated that the loss of activity in the triolein-grown cells was probably not due to direct inhibition (by fatty acyl-CoA esters as shown by Boulton \& Ratledge, 1983a) but was either due to repression or protein inactivation.

Malic enzyme. Malic enzyme occurs in the cytosol and its putative role in lipogenesis is to prove NADPH for fatty acid biosynthesis (Botham \& Ratledge, 1979; Ratledge, 1986, 1987). Table 1 shows that when the yeasts were utilizing their own endogenous lipid there were only small changes in malic enzyme activity (up to $45 \%$ decrease). However, when yeasts were grown on exogenous lipid (triolein), there was a clear decrease in the enzyme activity, and in two species it was undetectable.

$C A T$. CAT serves to transport acetyl units into and out of the mitochondria and peroxisomes (Kohlaw \& Tan-Wilson, 1977; Fukui \& Tanaka, 1979a). Table 1 shows that activities of this enzyme were low during lipid accumulation but very high during growth on triolein as sole carbon source. During utilization of endogenous lipid reserves, the activities of the enzyme were similar to those during lipid accumulation.

$I C L$. This enzyme is one of the key enzymes of the glyoxylate cycle and is located in the peroxisomes of $n$-alkane-grown yeasts (Fukui \& Tanaka, 1979 $a, b$ ). It regulates the simultaneous operation of the tricarboxylic acid and glyoxylate cycles and is induced in cells grown on $\mathrm{C}_{2}$ compounds such as ethanol or acetate, or on fatty acids, which are degraded to $\mathrm{C}_{2}$ compounds. $\mathrm{A}$ clear induction of ICL was seen in each yeast strain examined during growth on the exogenous lipid (triolein) and when utilizing endogenous lipid (carbon starvation media) (Table 1). The activity of the enzyme was negligible during lipid accumulation. 
Table 2. Enzyme activities in $C$. curvata $D$ during growth on nitrogen-limited medium (lipid accumulation) and carbon-starvation medium (endogenous lipid degradation) in a two-stage chemostat

$\begin{array}{cccccccc}\begin{array}{c}\text { Growth } \\ \text { medium }\end{array} & \begin{array}{c}\text { Dilution } \\ \text { rate }\left(\mathrm{h}^{-1}\right)\end{array} & \text { ACL } & \text { CAT } & \text { Catalase } & \text { ICDH } & \text { ICL } & \begin{array}{c}\text { Malic } \\ \text { enzyme }\end{array} \\ \text { and stage* } & \text { Enzyme activity [nmol (mg protein) })^{-1} \text { ] } & & \\ \text { Stage 1 NLM } & 0.05 & 29 & 50 & 21 \times 10^{3} & 102 & 1 & 24 \\ \text { Stage 2 CSM } & 0.05 & 1 & 220 & 30 \times 10^{3} & 81 & 143 & 20\end{array}$

*NLM, nitrogen-limited medium (steady state); CSM, carbon starvation medium (steady state).

$I C D H$. This enzyme is reported to be present in the peroxisomes of yeasts (Fukui \& Tanaka, $1979 a, b)$. In the four yeasts studied, there was a slight increase in ICDH activity during growth on exogenous lipid but there was no significant increase in activity during growth on endogenous lipid (Table 1).

Catalase. This enzyme is regarded as a marker enzyme for peroxisomes (Fukui \& Tanaka, $1979 a, b)$. Catalase was present in all four yeast strains when accumulating lipid - and such yeasts did not show peroxisomal proliferation (see below: 'Electron microscopy') - and also when utilizing exogenous and endogenous lipid sources (Table 1). However, the changes in specific activity of the enzyme were slight and variable, increasing in C. curvata and T. cutaneum during lipid utilization but decreasing in $R$. toruloides.

Enzymic changes accompanying lipid degradation in continuous culture.

A study of the enzymes examined in batch culture was done using $C$. curvata $\mathrm{D}$ as a model oleaginous yeast growing in a two-stage continuous culture. This was done to avoid the inherent dangers of sampling batch culture to obtain data then believed to be 'typical' of the behaviour of the organisms under observation. The first stage was with nitrogen-limited medium and thus produced lipid-rich cells; the second stage was fed with the carbon starvation medium. Enzyme activities (Table 2) were studied in cells being held under steady-state conditions in the two chemostats and were similar to those observed in the previous batch culture. ACL was clearly repressed (or inactivated) during lipid utilization. CAT and ICL were both stimulated to a significant extent during lipolysis. Activities of malic enzyme, catalase and ICDH were similar to those obtained in batch culture in that they changed only slightly during endogenous lipid utilization. This study clearly indicated which were the major enzymes responding to carbon starvation and lipid utilization.

\section{Electron microscopy}

Ultrastructural studies were undertaken with the yeasts Candida curvata D and Lipomyces starkeyi CBS 1809 to establish whether or not peroxisomal proliferation was associated with the degradation of exogenous and endogenous lipid in these yeasts. L. starkeyi was included in this study as a yeast which showed only a very modest ability to mobilize its lipid reserves-less than $18 \%$ of its accumulated lipid was used during $36 \mathrm{~h}$ starvation (Holdsworth \& Ratledge, 1987) whereas $C$. curvata used over $75 \%$ of its lipid under similar conditions. Figs $1-5$ show electron micrographs of the two yeasts grown to effect lipid accumulation (Figs 1 and 4), those grown under carbon-starvation conditions to stimulate endogenous lipid utilization (Figs 2 and 5) and, for $C$. curvata only, grown on an exogenous lipid source (Fig. 3.)

When cultivated on nitrogen-limited medium (Figs 1 and 4), both yeasts contained (apart from the usual cell organelles, such as nuclei, mitochondria, vacuoles and endoplasmic reticulum) either several lipid globules or one large globule. In addition, another storage 


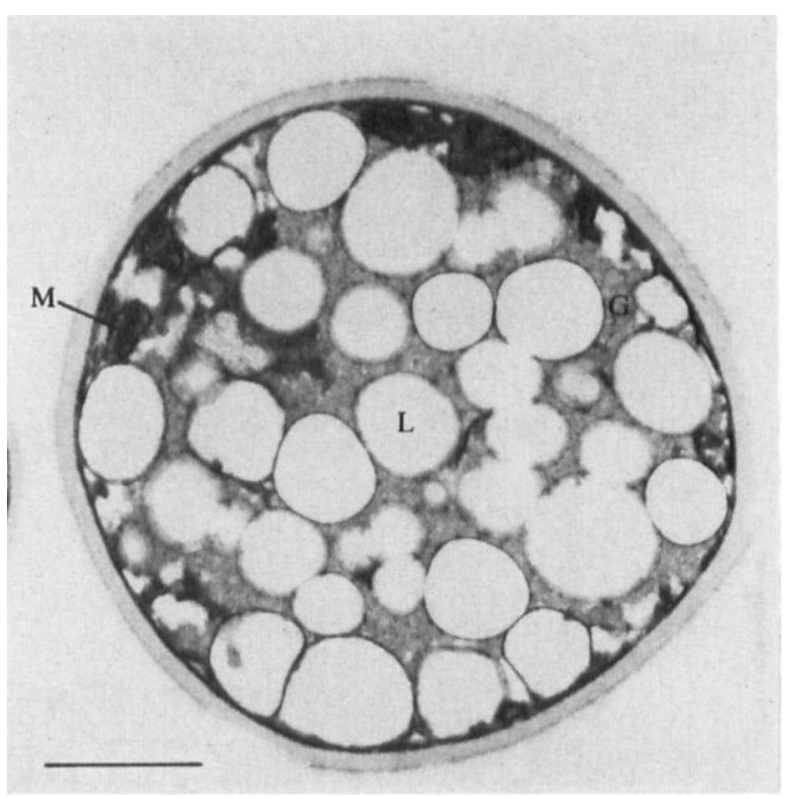

Fig. 1. C. curvata $\mathrm{D}$ grown for $2 \mathrm{~d}$ on nitrogen-limited medium. There is an obvious abundance of lipid droplets (L), with some mitochondria (M) also present. Glycogen granules (G) are also evident. Bar, $1 \mu \mathrm{m}$.

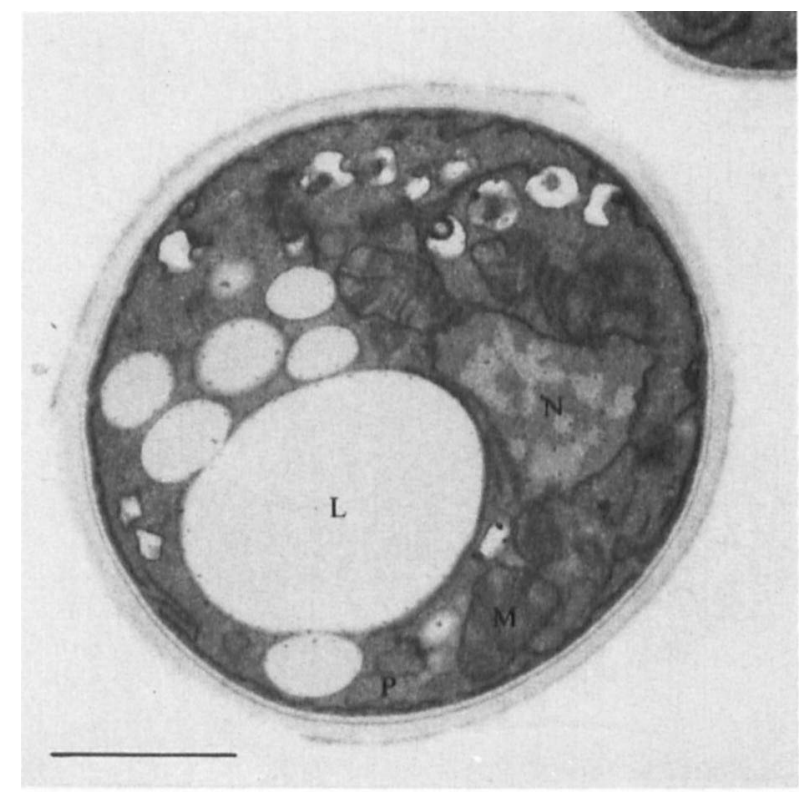

Fig. 2. C. curvata D grown initially as in Fig. 1 then held for $18 \mathrm{~h}$ in a carbon-starvation medium. A few peroxisomes $(P)$ are now visible along with some lipid droplets $(L)$. The nucleus $(N)$ is clearly evident. Bar, $1 \mu \mathrm{m}$. 


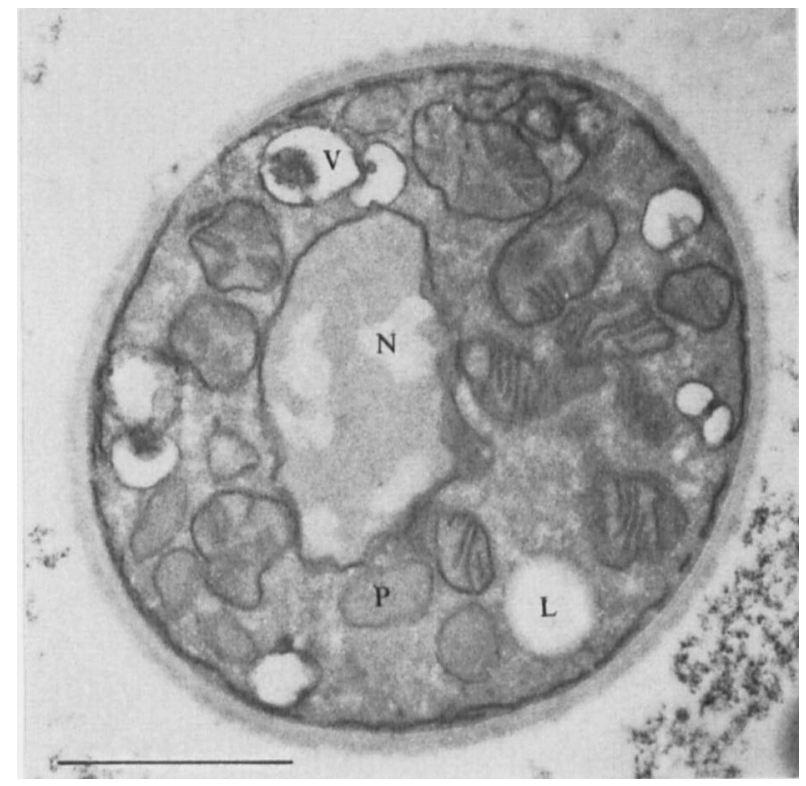

Fig. 3. C. curvata grown for $24 \mathrm{~h}$ on triolein. Only a small number of lipid droplets (L) are now visible; peroxisomes (P) are much in evidence. Vacuoles (V) are also seen. Bar, $1 \mu \mathrm{m}$.

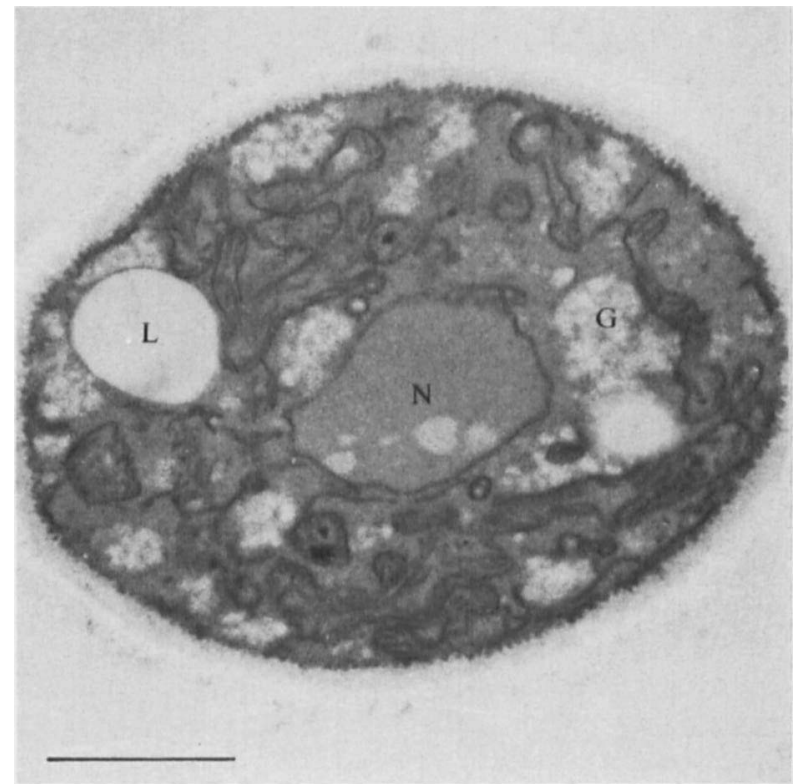

Fig. 4. L. starkeyi NCYC 1809 grown for $2 \mathrm{~d}$ on nitrogen-limited medium. The lipid droplets (L) are more diffuse than in C. curvata. Glycogen $(\mathrm{G})$ is again present but no peroxisomes are in evidence. Bar, $1 \mu \mathrm{m}$. 


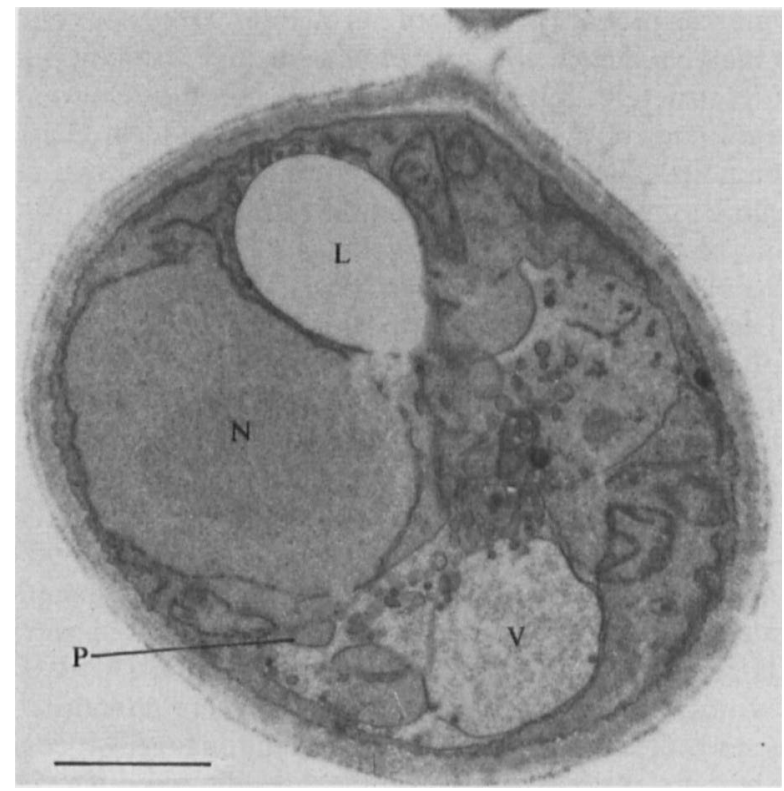

Fig. 5. L. starkeyi NCYC 1809 grown initially as in Fig. 4 then held for $18 \mathrm{~h}$ in a carbon starvation medium. Only a single lipid droplet (L) is seen with an occasional small peroxisome (P). Bar, $1 \mu \mathrm{m}$.

product, thought to be glycogen (Holdsworth \& Ratledge, 1987), was also present (Figs 1 and 4). Proliferation of peroxisomes was not observed in these cells though the occasional one could be seen in some cross-sections.

Thin sections of $C$. curvata D which had been starved for $18 \mathrm{~h}$ (Fig. 2) showed an obvious decrease in the lipid content of the cell and nearly all of the glycogen granules had disappeared. There was an increase in peroxisome number and volume fraction compared to the glucosegrown cells. During growth of $C$. curvata D on triolein (Fig. 3) the cells contained small lipid globules but no glycogen. In addition, many peroxisomes were present in the cells.

L. starkeyi CBS 1809 contained a large lipid droplet even when starved of carbon and, although only a small amount of lipid would have been degraded (see Holdsworth \& Ratledge, 1987), the occasional small peroxisome was detected (Fig. 5).

\section{DISCUSSION}

Previously, we noted the ability of oleaginous yeasts to degrade their storage lipid rapidly under carbon-starvation conditions, indicating lipid metabolism to be highly controlled (Holdsworth \& Ratledge, 1987). It was therefore expected that key enzymes involved in this process would also be tightly controlled within the cell.

The activity of ACL, which plays a key role in lipid biosynthesis by furnishing acetyl-CoA for fatty acid biosynthesis (Botham \& Ratledge, 1979), was high during lipid accumulation but was greatly decreased during growth on either internal storage lipid or the external lipid source. This is similar to the recent report by Naganuma et al. (1987) for $L$. starkeyi that ACL activity was also high during lipid accumulation but greatly reduced during cell proliferation. ACL is inhibited by fatty acyl-CoA esters (Boulton $\&$ Ratledge, 1983 $a, b$ ), which are the first breakdown products of triacylglycerol degradation; although this could bring about the rapid cessation of enzyme activity, on mixing of extracts from both types of cell (triolein grown and nitrogenlimited) the resultant specific activity was approximately half the individual activities. This 
indicated that the enzyme was probably repressed during both exogenous and endogenous lipid utilization, although it may have been converted to an inactive form by phosphorylation or a similar modification of its structure. Inhibition by fatty acyl-CoA esters would therefore be the means of achieving rapid control over lipid biosynthesis; long-term control is probably by repression. It should be noted that ACL is still active in glucose-grown cells under carbonlimiting (non-lipid accumulating) conditions (Boulton \& Ratledge, 1983b).

The activity of malic enzyme, which is thought to have an integral role in fatty acid biosynthesis in providing NADPH (Ratledge, 1986, 1987), was also diminished in all four yeasts grown on triolein and became undetectable in two of them. However, specific activities of the enzyme during utilization of endogenous lipid reserves were similar to those observed during lipid accumulation both in continuous and in batch culture (Tables 1 and 2), indicating that the condition of intracellular lipid utilization may be subtly different from that of extracellular lipid utilization. This mid-way position was also seen with the CAT activities.

CAT transfers acetyl units both into and out of the mitochondrion (Kohlaw \& Tan-Wilson, 1977) for, respectively, either subsequent degradation via tricarboxylic acid cycle or fatty acid biosynthesis. In oleaginous yeasts, this activity serves as a minor supplementary pathway to the citrate efflux system coupled with ACL (Ratledge \& Gilbert, 1985). This enzyme also occurs in the peroxisomes (Ueda et al., 1982) for the efflux of acetyl units derived from fatty acid degradation. CAT activities were considerably enhanced during growth on triolein in all the yeasts examined in this study (Table 1), agreeing with the findings of Ratledge \& Gilbert (1985) and suggesting CAT to be a major peroxisomal enzyme. Specific activities were not significantly enhanced during utilization of endogenous lipid reserves in batch culture but were more clearly increased in the chemostat study of lipid utilization (see Table 2).

Catalase, ICL, ICDH and CAT are considered to be peroxisomal enzymes (Fukui \& Tanaka, $1979 a, b, 1981)$. Development of the peroxisomes themselves is induced by growing yeasts on alkanes or higher fatty acids (Teranishi et al., 1974; Veenhuis et al., 1987), which are then degraded to acetyl-CoA exclusively in these peroxisomes (Fukui \& Tanaka, 1981; Boulton \& Ratledge, 1984). It has been hitherto uncertain whether peroxisomes would also be induced in yeasts which were utilizing their own intracellular stores of lipid but this has now been shown to be the case with $C$. curvata $\mathrm{D}$ (Fig. 2) and also with the other oleaginous yeasts of this study (Holdsworth, 1987). Only with L. starkeyi, where utilization of lipid reserves is minimal and the yeast cannot grow on exogenous lipid, was the induction of peroxisomes also minimal (see Fig. $5)$.

Of the four putative peroxisomal enzymes, only CAT and ICL were clearly enhanced in activity in the yeasts utilizing exogenous lipid. Increases in the activity of ICDH with increasing peroxisome function varied between 33 and $50 \%$ in the four yeasts but catalase activity increased in two yeasts and decreased in the other two. Thus although the former enzyme may have some association with peroxisomes, it is clear that neither it nor catalase can be exclusively associated with these organelles.

With only the occasional peroxisome being seen in L. starkeyi under carbon-starvation conditions, it might be argued that the inability of this yeast to utilize its lipid reserves rapidly is due to its inability to form peroxisomes in any number.

Yeasts utilizing their own endogenous lipid reserves would seem to form fewer peroxisomes than when they are growing on externally supplied lipid. This limited induction of peroxisomes may however reflect the constrained conditions of carbon starvation which had to be imposed to achieve intracellular lipid utilization. Endogenous and exogenous lipid utilization is thus achieved by the induction of peroxisomes and is coupled with the cessation of lipid synthesis as evidenced by the strong repression of both ACL and malic enzyme whose putative role in lipid formation now becomes more firmly established by these findings.

We are grateful to Cadbury-Schweppes plc for their co-operation with this research through an SERC-CASE award to J.E.H. Dr R. Gibson and R. Moreton are thanked for their continued interest in the work. 


\section{REFERENCES}

Botham, P. A. \& Ratledge, C. (1979). A biochemical explanation for lipid accumulation in Candida 107 and other oleaginous micro-organisms. Journal of General Microbiology 114, 361-375.

Boulton, C. A. \& Ratledge, C. (1983a). Partial purification and some properties of ATP : citrate lyase from the oleaginous yeast Lipomyces cerevisiae. Journal of General Microbiology 129, 28632869.

Boulton, C. A. \& Ratledge, C. (1983b). Use of transition studies in continuous cultures of Lipomyces starkeyi, an oleaginous yeast, to investigate the physiology of lipid accumulation. Journal of General Microbiology 129, 2871-2876.

Boulton, C. A. \& Ratledge, C. (1984). The physiology of hydrocarbon-utilizing micro-organisms. In Topics in Enzyme and Fermentation Biotechnology, pp. 11-77. Edited by A. Wiseman. Chichester: Ellis Horwood.

BRADFORD, M. M. (1976). A rapid and sensitive method for the quantitation of microgram quantities of protein utilizing the principle of protein-dye binding. Analytical Biochemistry 72, 248-254.

FukUi, S. \& TANAKA, A. (1979a). Peroxisomes of alkane- and methanol-grown yeasts. Journal of Applied Biochemistry 1, 171-201.

FUKUI, S. \& TANAKA, A. $(1979 b)$. Yeast peroxisomes. Trends in Biochemical Sciences 4, 246-249.

FUKUI, S. \& TANAKA, A. (1981). Metabolism of alkanes by yeasts. Advances in Biochemical Engineering 19, 217-237.

HOLDSWORTH, J. E. (1987). Aspects of lipid metabolism in oleaginous yeasts. $\mathrm{PhD}$ thesis, Hull University.

HoldsworTH, J. E. \& RATLEDGE, C. (1986). Utilization of accumulated lipid by oleaginous yeasts. XIth International Specialized Symposium on Yeasts, Lisbon, p. 66.

Holdsworth, J. E. \& Ratledge, C. (1987). Lipid turnover in oleaginous yeasts. Journal of General Microbiology 134, 339-346.

Hsu, R. Y. \& LARDY, H. A. (1969). Malic enzyme. Methods in Enzymology 13, 230-235.
Kohlaw, G. B. \& TaN-Wilson, A. (1977). Carnitine acetyltransferase: candidate for the transfer of acetyl groups through the mitochondrial membrane of yeast. Journal of Bacteriology 129, 1159-1161.

KORNBERG, A. (1955). Isocitrate dehydrogenase of yeast. Methods in Enzymology 1, 705-709.

MCFADDEN, B. A. (1969). Isocitrate lyase. Methods in Enzymology 13, 163-170.

Marshall, B. J., Ratledge, C. \& Norman, E. (1973). Improved design for a simple and inexpensive multilace laboratory fermenter. Laboratory Practice, 22, 491-492.

Naganuma, T., Uzuka, Y., TaNaka, K \& IIzUKa, H. (1987). Differences in enzyme activities of Lipomyces starkeyi between cells accumulating lipid and proliferating cells. Journal of Basic Microbiology 27, 35-42.

RATLEDGE, C. (1986). The potential of micro-organisms for oil production - a review of recent publications. In Proceedings of the World Conference on Emerging Technologies within the Fats and Oils Industry, pp. 318-330. Edited by A. R. Baldwin. Champaign, Illinois: American Oil Chemists' Society.

RATLEDGE, C. (1987). Lipid biotechnology - a wonderland for the microbial physiologist. Journal of the American Oil Chemists' Society 64, 1647-1656.

Ratledge, C. \& Gilbert, S. C. (1985). Carnitine acetyltransferase activity in oleaginous yeasts. FEMS Microbiology Letters 27, 273-275.

SRere, P. A. (1962). Citrate cleavage enzyme. Methods in Enzymology 5, 641-644.

Teranishi, Y., Kowamoto, S., Tanaka, A., Osumi, M. \& FUKUI, S. (1974). Induction of catalase activity by hydrocarbons in Candida tropicalis. Agricultural and Biological Chemistry 38, 1221-1225.

Ueda, M., Tanaka, A. \& Fukui, S. (1982). Peroxisomes and mitochondrial carnitine acetyltransferases in alkane-grown yeast Candida tropicalis. European Journal of Biochemistry 124, 205-210.

VeEnhuis, M., Mateblowski, M., Kunau, W. H. \& HARDER, W. (1987). Proliferation of microbodies in Saccharomyces cerevisiae. Yeast 3, 77-84. 